\title{
IMPROVING THE STUDENTS' PERFORMANCE FROM THE EXPECTATION AND QUALITY OF LEARNING
}

\author{
Khusaini Khusaini ${ }^{*}$ \\ Budi Luhur University \\ Ciledug Raya St., Jakarta Selatan \\ Indonesia 12260 \\ kkhusaini541@gmail.com
}

\author{
Ali Sandy Mulya ${ }^{2}$ \\ Budi Luhur University \\ Ciledug Raya St., Jakarta Selatan \\ Indonesia 12260 \\ alisandy@outlook.com
}

\begin{abstract}
This research aims to measure expectations, gender, learning quality, and control variables on the performance of the undergraduate program of Accounting at Tangerang Municipality. The target population is 1,898 students, with 331 of them becoming the sample. The sampling technique was Disproportionate Random Sampling and used a Binary Probit Regression. The distribution of the questionnaires used a Google Form. The results showed that the expectations and quality of learning had a significant effect on improving performance. On the other hand, gender was insignificant. This study's findings contribute to universities always maintaining student expectations and the quality of learning so that graduates have good performance.
\end{abstract}

Keywords: Accounting; Undergraduate Student; Gender; Tangerang; Binary Probit Regression

\section{ABSTRAK}

Penelitian ini bertujuan untuk menguji harapan, gender, kualitas pembelajaran, dan variabel kontrol terhadap kinerja mahasiswa program sarjana S-1 Akuntansi di Perguruan Tinggi Kota Tangerang. Populasi sebanyak 1.898 mahasiswa dan ukuran sampel sebanyak 331 sampel. Teknik sampling adalah disproportionate random sampling dan menggunakan analisis binary probit regression. Distribusi kuesioner menggunakan google form. Hasil penelitian menunjukkan bahwa harapan dan kualitas pembelajaran berpengaruh signifikan terhadap peningkatan kinerja mahasiswa, sebaliknya gender tidak signifikan. Temuan penelitian ini memberikan konstribusi kepada perguruan tinggi untuk selalu menjaga ekspektasi mahasiswa dan mutu pembelajaran agar para lulusannya memiliki kinerja yang baik.

Kata Kunci :

Akuntansi; Mahasiswa Program Sarjana; Jenis

JEL Classification: Kelamin; Tangerang; Regresi Binary Probit A22; M49

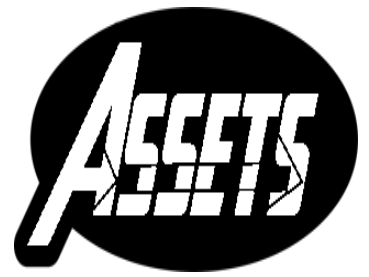

ASSETS

Jurnal Akuntansi dan Pendidikan

Vol. 10 No. 2

Page 147-164

Madiun, October 2021 p-ISSN: 2302-6251 e-ISSN: 2477-4995

Article History Submitted: February 10, 2021 Accepted:

October 29, 2021 


\section{INTRODUCTION}

One of the critical issues today is how to prepare graduates who have good performance to compete in the global economy. Because of the failure to prepare students who perform well and sacrifice emotional costs, school fees also reduce the provision of professional personnel (Gracia \& Jenkins, 2002). Therefore, good academic performance serves as a stepping stone for accounting students in their quest to pursue a career in accounting (Ahinful et al., 2019). A good student's performance can be achieved through evaluation activities and competitions or tournaments outside the campus (Arumsari, 2017). Students are taught accounting concepts and principles to develop strong analytical skills (Papageorgiou \& Callaghan, 2020) and language, business, and information technology skills (Papageorgiou, 2017). Students' performance in college can be used as a basis for accounting students in their pursuit of a career in accounting (Ahinful et al., 2019). Universities are responsible for creating high-quality and outstanding students. The goals attain job market standards and reach the demand for the accountant labor market, particularly in developing countries (Bakre \& Lauwo, 2016; Dalc1 et al., 2013).

Many previous researchers have investigated the determinants of students' performance in accounting studies, such as students' performance-related ability to change, adapt, make difficult decisions, learn from mistakes, and control changes in belief and choice (Feldman et al., 2016). Meanwhile, other researchers included locus of control, learning methods and learning resources (Litasari \& Pustikaningsih, 2019), expectations, volition, interests, and attitude during learning (Ahinful et al., 2019; Byrne \& Flood, 2005), gender and personality (Fallan \& Opstad, 2014), gender and parental style (Papageorgiou \& Callaghan, 2018a).

Expectation is something that someone or an individual wants to achieve in the future. Vroom (1964) considered expectations as the possibility of a subjective actionoriented to results or performance. A process of individual thinking towards goals, motivation, and ways to achieve goals is also considered a theory of expectation (Feldman et al., 2016). The effect of students' expectations on the performance of undergraduate accounting students is explained by choice theory. Using expectation theory in predicting academic performance, students have realistic expectations of acquiring broad knowledge and skills development when studying higher education (Arquero et al., 2009; Byrne \& Flood, 2005). Research conducted by (Ahinful et al., 2019; Alindra, 2015; Guney, 2009) concluded a significant correlation between students' expectations and academic performance. It infers that students who expect better results should make a reasonable effort.

On the other side, expectations did not correlate to students' performance. As concluded in previous studies, students who expect to succeed in the future do not have a significant correlation with final grades (Eikner \& Montondon, 2001). Byrne \& Flood (2008) also confirmed previous studies that students' high expectations did not significantly correlate with their performance. The results also found that expectations insignificantly correlated with the results of a course named Financial Accounting I (Arquero et al., 2009). Students with higher abilities have higher expectations of general skills learning outcomes (Smith et al., 2018).

The role of gender in improving the performance of accounting students is critical. Previous studies have shown that gender significantly affects improving student performance (Alanzi, 2018; Fallan \& Opstad, 2014; Papageorgiou \& Callaghan, 2018b; Wijaya \& Amah, 2012). Moreover, (Aditya \& Hasibuan, 2020; Guney, 2009) stated that gender differences would impact student academic performance, including career choices and learning motivation. These differences are not only from the 
academic side but also in determining the learning method to improve their performances. However, other previous studies generated the opposite research findings, that gender differences do not have a significant correlation between improving the performance of accounting students (Feldman et al., 2016; Kukreja \& Al Ali, 2013).

Learning in the classroom also determines changes in students' performance because it involves all the resources in the classroom. Previous studies found that the quality of instructional learning could improve academic achievement (Fauth et al., 2014; Kunter et al., 2013). Meanwhile, personalized learning that focuses on teachers' teaching has significantly improved students' achievement (Pane et al., 2017). The quality of learning as measured by knowledge activation and the carrying capacity of the classroom climate affected the improvement of student competence in accounting significantly (Helm, 2015). Finally, Parsons et al. (2020) also found that learning program activities and teachers' quality, using the proper method, could improve the accounting skills of graduates. However, there are studies with opposite findings. The finding showed that time allocation and characteristics of learning and teachers at schools did not statistically significantly affect educational outcomes (Glewwe et al., 2011).

Based on the studies explained above, there are important variables that affect students' performance; the quality of learning in class. The authors argue that the better the learning quality process, the more students can improve their knowledge, understanding, and accounting practice. Several previous studies still focus on predictor variables such as demographic variables, the role of parents, motivations, expectations, and volitions to predict student performance. Therefore, the presence of this study is to add the variable of learning quality (Fauth et al., 2014; Kunter et al., 2013; Li et al., 2020; Longobardi et al., 2018; Praetorius et al., 2018) as one of the predictors. Learning quality variables will further complement previous research and contribute to the literature about student performance. In addition, the use of variables investigated by previous researchers showed gaps or inconsistencies, such as expectations, gender, and learning quality. The authors examine expectation, gender, and the quality of learning variables to the student's performance in the accounting program.

\section{METHOD}

This study applied a cross-sectional survey approach. The target population size in this study was all students registered and active in the undergraduate Accounting program at the Tangerang Municipality for the academic year 2015/2016 - 2019/2020. The target population was universities with an accounting study program, had graduates, accredited B, and their leaders allowed them to be the object of research. Universities that meet the criteria for the target population are 2 out of 12 units. We decided 2 (two) universities were examined, namely the Muhammadiyah University of Tangerang (UMT) and the Islamic University of Syekh-Yusuf (UNIS). The target population in this study was 1.898 students. The authors determined to select disproportionate random sampling because UMT students were almost five times larger than the number of UNIS students. It was not proportionate (Sugiyono, 2017). The sample size was determined by using the Slovin formula with the sampling error was $5 \%$. The formulation process gets a sample size of as many as 331 samples. We decided to distribute the questionnaire to all active and registered students at the universities using Google Form (via WA group). The questionnaire was returned and 
filled with 343 units. In addition, we selected a questionnaire so that 331 samples were obtained. The contributors from the Islamic University of Syekh-Yusuf were as much as $34.44 \%$ or 114 of the total sample. In comparison, the sample size from the Muhammadiyah University of Tangerang is $65.56 \%$ or 217 samples.

The authors also conducted a trial as a pilot test on 90 (ninety) respondents from the Syekh-Yusuf Islamic University on 1 - 20 December 2020, determined by purposive sampling. The students who were the respondents for the pilot test were multi-level and Accounting study program students. The students of the two universities were identical (according to the characteristics of the population). The pilot test mentioned earlier referred to the tests of validity (Biserial Correlation) and reliability. The validity test results showed that the instrument for questioning student performance, expectations, motivation, volitions, preparedness, interest in learning, and learning attitudes variables was valid at $\alpha<0.05$.

Meanwhile, there is 1 question is invalid from the variable of parental style and four questions from learning quality. It was invalid five questions and was not used. Furthermore, the measurement of the dependent and independent variables can be seen in Table 1 below.

Table 1. Operationalization of Variables

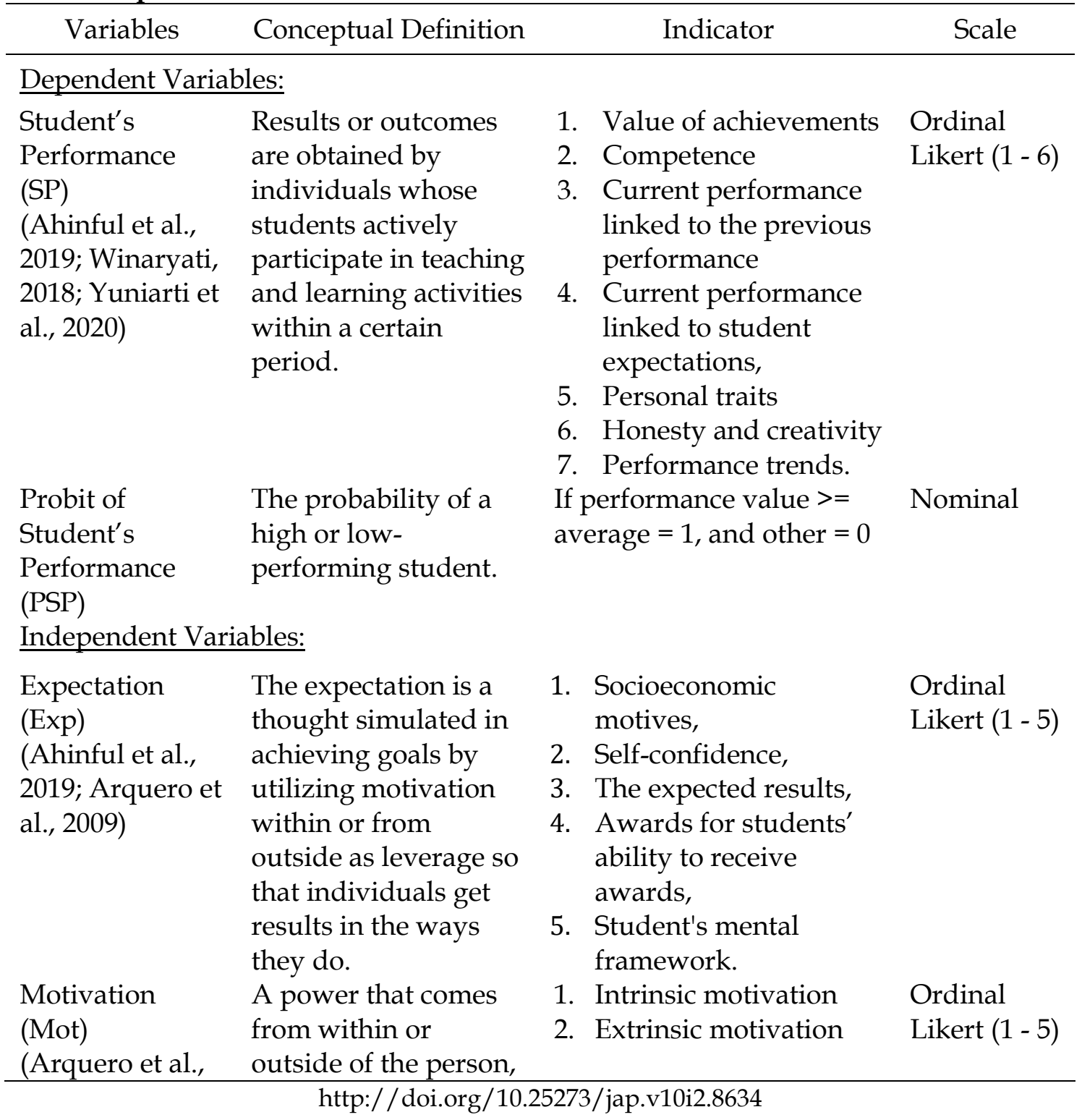




\begin{tabular}{|c|c|c|c|}
\hline Variables & Conceptual Definition & Indicator & Scale \\
\hline 2009). & $\begin{array}{l}\text { possessed by a person } \\
\text { to carry out activities. }\end{array}$ & & \\
\hline $\begin{array}{l}\text { Volition (Vol) } \\
\text { (Ahinful et al., } \\
\text { 2019; Dalc1 et al., } \\
\text { 2013) }\end{array}$ & $\begin{array}{l}\text { Actions are taken by } \\
\text { individuals (students) } \\
\text { consciously to } \\
\text { determine, select and } \\
\text { defend their behavior } \\
\text { that involves mental } \\
\text { changes to achieve } \\
\text { learning goals. }\end{array}$ & $\begin{array}{l}\text { 1. Objectives to be } \\
\text { achieved } \\
\text { 2. Reasons for choosing a } \\
\text { program } \\
\text { 3. Pressure } \\
\text { 4. Independence in } \\
\text { learning }\end{array}$ & $\begin{array}{l}\text { Ordinal } \\
\text { Likert }(1-5)\end{array}$ \\
\hline $\begin{array}{l}\text { Gender (Gen) } \\
\text { (Alanzi, 2018; } \\
\text { Feldman et al., } \\
\text { 2016; } \\
\text { Papageorgiou \& } \\
\text { Callaghan, } \\
\text { 2018a, 2020) }\end{array}$ & $\begin{array}{l}\text { Biological differences } \\
\text { are coded by using } \\
\text { dummy variables. }\end{array}$ & $\begin{array}{l}\text { Students Gender (if } \\
\text { Female }=1 \text {, Male }=0 \text { ) }\end{array}$ & Nominal \\
\hline $\begin{array}{l}\text { Parental Style } \\
\text { (PS) } \\
\text { (Papageorgiou } \\
\text { \& Callaghan, } \\
\text { 2018) }\end{array}$ & $\begin{array}{l}\text { Specific parental } \\
\text { behavior shapes } \\
\text { children's behavior } \\
\text { and development } \\
\text { during parenting, } \\
\text { whether in } \\
\text { authoritarian, } \\
\text { permissive, } \\
\text { authoritative, or other } \\
\text { forms. }\end{array}$ & $\begin{array}{l}\text { 1. Authoritarian } \\
\text { 2. Authorization } \\
\text { 3. Permissive } \\
\text { 4. Inattentive }\end{array}$ & $\begin{array}{l}\text { Ordinal } \\
\text { Likert }(1-5)\end{array}$ \\
\hline $\begin{array}{l}\text { Quality of } \\
\text { Learning (QL) } \\
\text { (Li et al., 2020; } \\
\text { Longobardi et } \\
\text { al., 2018; } \\
\text { Praetorius et al., } \\
\text { 2018) } \\
\text { Control Variable: }\end{array}$ & $\begin{array}{l}\text { Quality or } \\
\text { effectiveness in } \\
\text { achieving learning } \\
\text { objectives measured } \\
\text { by student's optimal } \\
\text { learning outcomes }\end{array}$ & $\begin{array}{l}\text { 1. Classroom } \\
\text { management } \\
\text { 2. Student support } \\
\text { 3. Knowledge Activation }\end{array}$ & $\begin{array}{l}\text { Ordinal } \\
\text { Likert }(1-5)\end{array}$ \\
\hline Grade (Gr) & $\begin{array}{l}\text { The grade is the level } \\
\text { or semester at which } \\
\text { the student is enrolled }\end{array}$ & Level/semester & $\begin{array}{l}\text { Ordinal } \\
\text { Likert }(1-5)\end{array}$ \\
\hline $\begin{array}{l}\text { Academic } \\
\text { Interest (AI) } \\
\text { (Ahinful et al., } \\
\text { 2019) }\end{array}$ & $\begin{array}{l}\text { Academic interest is a } \\
\text { student's interest in } \\
\text { accounting study } \\
\text { programs related to } \\
\text { activities or objects of } \\
\text { interest with positive } \\
\text { emotional experiences } \\
\text { and personal value } \\
\text { systems. }\end{array}$ & $\begin{array}{l}\text { 1. Accounting is not the } \\
\text { primary choice. } \\
\text { 2. The intensity of } \\
\text { studying accounting } \\
\text { 3. Discomfort in reading } \\
\text { accounting courses }\end{array}$ & $\begin{array}{l}\text { Ordinal } \\
\text { Likert }(1-5)\end{array}$ \\
\hline
\end{tabular}


KHUSAINI, K. \& MULYA, A. S. IMPROVING THE STUDENTS PERFORMANCE ...

\begin{tabular}{|c|c|c|c|}
\hline Variables & Conceptual Definition & Indicator & Scale \\
\hline $\begin{array}{l}\text { Learning } \\
\text { Attitude (LA) } \\
\text { (Ahinful et al., } \\
\text { 2019) }\end{array}$ & $\begin{array}{l}\text { Learning attitude is } \\
\text { an attitude that is } \\
\text { formed within } \\
\text { students towards } \\
\text { accounting courses. }\end{array}$ & $\begin{array}{l}\text { 1. Time to read } \\
\text { accounting lessons } \\
\text { 2. Learn something new } \\
\text { (accounting) } \\
\text { 3. The effort to read } \\
\text { accounting lessons }\end{array}$ & $\begin{array}{l}\text { Ordinal } \\
\text { Likert }(1-5)\end{array}$ \\
\hline $\begin{array}{l}\text { Preparedness } \\
\text { (P) } \\
\text { (Arquero et al., } \\
\text { 2009; Byrne \& } \\
\text { Flood, 2005) }\end{array}$ & $\begin{array}{l}\text { Preparedness is a } \\
\text { student's readiness } \\
\text { during lectures, both } \\
\text { psychologically and } \\
\text { physically. }\end{array}$ & $\begin{array}{l}\text { 1. Initiative and activity } \\
\text { planning } \\
\text { 2. Responsibility } \\
\text { 3. Self-confidence } \\
\text { 4. Comfort } \\
\text { 5. Willing to cooperate } \\
\text { 6. Ability to evaluate }\end{array}$ & $\begin{array}{l}\text { Ordinal } \\
\text { Likert }(1-5)\end{array}$ \\
\hline $\begin{array}{l}\text { Age (A) } \\
\text { (Papageorgiou } \\
\text { \& Callaghan, } \\
\text { 2018a) }\end{array}$ & $\begin{array}{l}\text { Maturity level in } \\
\text { thinking, behaving } \\
\text { and acting from } \\
\text { students. }\end{array}$ & Student's age & Interval \\
\hline Not Work (NW) & $\begin{array}{l}\text { Employment status is } \\
\text { a condition that } \\
\text { indicates the status of } \\
\text { the student in his/her } \\
\text { primary job. }\end{array}$ & If not work $=1$, other $=0$ & Nominal \\
\hline Time $(\mathrm{T})$ & $\begin{array}{l}\text { The choice of time is } \\
\text { chosen by students } \\
\text { when studying in the } \\
\text { Accounting program. }\end{array}$ & If morning $=1$, other $=0$ & Nominal \\
\hline $\begin{array}{l}\text { Career Choice } \\
\text { (CC) }\end{array}$ & $\begin{array}{l}\text { The choice of student } \\
\text { accounting profession } \\
\text { after completing } \\
\text { studies of } \\
\text { undergraduate } \\
\text { Accounting }\end{array}$ & $\begin{array}{l}\text { Scoring the number of } \\
\text { choice of the accounting } \\
\text { profession from high to } \\
\text { low with a range of } 5-1\end{array}$ & Interval \\
\hline
\end{tabular}

The authors used the Probit Regression Model (PRM) to examine the determinant of the performance of undergraduate accounting students. It is a model of the binary dependent variable and the development of the Logit Regression Model. Binary dependent variables are an example of a finite dependent variable (Wooldridge, 2018). The authors specified an analysis model to test the relationship between variables by adapting the model developed (Glewwe et al., 2011; Glewwe \& Kremer, 2005) and completing it with the model of (Ahinful et al., 2019; Papageorgiou \& Callaghan, 2020) so that the equation of the probit model is written as follows:

$$
\begin{aligned}
& P_{i}=P(S P=1 \mid X)=\beta_{0}+\beta_{1} \text { Exp }+\beta_{2} \text { Mot }+\beta_{3} \text { Vol }+\beta_{4} \text { Gen }+\beta_{5} P S+\beta_{6} Q L+ \\
& \beta_{7} G r+\beta_{8} A I+\beta_{9} L A+\beta_{10} \text { Prep }+\beta_{11} A+\beta_{12} N W+\beta_{13} t+\beta_{14} C C+\varepsilon
\end{aligned}
$$

Furthermore, the authors tested the effect of student expectations, gender, learning quality, and control variables on student performance by using the Wald Test and the Likelihood Ratio. We also estimated the average marginal effect of each 
variable to find out how much each change in the predictor variable affects the predicted variable (Ghozali, 2016; Wooldridge, 2018). The goodness of Fit testing model is used to test the feasibility of the model whether the model matches the data used in the study (Hair Jr et al., 2014). The next step is to determine the best model using Pseudo R2 or R2 McFadden so that the model can explain the data.

\section{RESULT AND DISCUSSION}

After collecting the data by using a questionnaire, the result of the research was described. There were 331 students' questionnaires in the undergraduate program of Accounting at Tangerang. The data were classified into gender, age, college, year of entry, and career choice. Table 2 below showed that the category of gender. The result showed 90 male students $(27.19 \%)$ and 241 female students $(72.81 \%)$. It means female students were dominant in the undergraduate program of Accounting. Furthermore, respondents aged between $19-23$ years were dominated by $87.92 \%$ of respondents. For more details, see table 2 below:

Table 2. The Classification of Samples into Gender, Age, College, Year of Entry, and Career Choice

\begin{tabular}{llrr}
\hline \multicolumn{1}{c}{ Characteristics } & \multicolumn{1}{c}{ Types } & Total & Percentages \\
\hline Gender & Male & 71 & $21.45 \%$ \\
Age & Female & 260 & $78.55 \%$ \\
& $<19$ years & 11 & $3.32 \%$ \\
College & 19 - 23 years & 291 & $87.92 \%$ \\
& $>23$ years & 29 & $8.76 \%$ \\
Year of entry & UNIS & 114 & $34.44 \%$ \\
& UMT & 217 & $65.56 \%$ \\
& $2015 / 2016$ & 4 & $1.21 \%$ \\
& $2016 / 2017$ & 30 & $9.06 \%$ \\
Carrier choice & $2017 / 2018$ & 166 & $50.15 \%$ \\
& $2018 / 2019$ & 64 & $19.34 \%$ \\
& $2019 / 2020$ & 67 & $20.24 \%$ \\
& Educator Accountant & 21 & $6.34 \%$ \\
& Government Accountant & 100 & $30.21 \%$ \\
& Public Accountant & 60 & $18.13 \%$ \\
& Firm Accountant & 142 & $42.90 \%$ \\
& Other & 8 & $2.42 \%$ \\
\hline
\end{tabular}

Table 2 also showed that the respondents of this research are students of Muhammadiyah Tangerang University (UMT) and Islamic University of Syekh-Yusuf (UNIS) Tangerang. There were $217(65.56 \%)$ students at UMT and $117(34.44 \%)$ students at UNIS. The number of respondents between the universities is not proportional because the population is not balanced. The number of students in each university is different. Furthermore, the research samples were chosen based on the category of career after graduating from the Accounting Program. Students who have planned to be Corporate/Firm Accountants in the future were the most chosen as samples of research. It can be seen that there was $42.90 \%$. Then, the least amount chosen profession being Education Accountant and others were 6.34\% and 2.42\%. 
Statistical description illustrated the result of each research variable that covered the main variables such as students' performance, expectations, gender, learning quality, and control variables. The researcher described the main variables employed in the research included the discussion of the result briefly. It is described in the following Table 3.

Table 3. Statistical Description

\begin{tabular}{ccrrrr}
\hline Variable & Obs & \multicolumn{1}{c}{ Mean } & Std. Dev. & \multicolumn{1}{c}{ Min } & \multicolumn{1}{c}{ Max } \\
\hline prob_sp & 331 & 0,498489 & 0,500755 & 0 & 1 \\
sp & 331 & 48,03779 & 7,268446 & 30,6 & 67,11 \\
exp & 331 & 30,91975 & 4,932319 & 15,63078 & 41,12825 \\
mot & 331 & 42,94903 & 6,857997 & 26,24432 & 58,84187 \\
vol & 331 & 24,08451 & 4,724213 & 11,77499 & 34,17598 \\
gen & 331 & 0,728097 & 0,445614 & 0 & 1 \\
ps & 331 & 50,085 & 10,10271 & 29,07308 & 68,16389 \\
q1 & 331 & 121,3454 & 18,40421 & 51,77492 & 161,5903 \\
p & 331 & 31,37215 & 5,50925 & 14,45612 & 42,56096 \\
ai & 331 & 10,77936 & 2,290524 & 5,672105 & 14,7754 \\
la & 331 & 9,870439 & 2,243912 & 3,858251 & 13,73899 \\
a & 331 & 21,17825 & 2,78768 & 17 & 48 \\
gr & 331 & 3,522659 & 0,82127 & 2 & 6 \\
t & 331 & 0,598187 & 0,491007 & 0 & 1 \\
cc & 331 & 4,02719 & 1,15831 & 1 & 5 \\
\hline
\end{tabular}

\section{Financial Target and Fraudulent Financial Reporting}

The data analysis, 331 students as the respondent, explained descriptively into mean (M) and standard deviation (SD) in each variable. Based on the Table 3, students' performance variable (SP) got the value: $[M=48,04, S D=7,27]$. The binary variable of students' performance in the undergraduate program of Accounting (prob_sp) obtained the value of $[\mathrm{M}=0498, \mathrm{SD}=0.50]$. It meant that the gains of students' performance were categorized medium level due to this average value between $[37,27$ - 51,72]. Meanwhile, the number of students belonging to the good category was $49.85 \%$, if their performance were categorized as two groups (binary).

The expectation variable produced an average value and standard deviation of $[M=30.92, S D=4.93]$. It meant that the level of students' expectation in achieving their goals after graduating from the Accounting Program was 68,71\%. It meant that the score was in a large category. Furthermore, the average value and standard deviation of gender category (Gen) were [M=0.728, $\mathrm{SD}=0.445]$. It can be inferred that there are more female students than male students in the Accounting Study Program at higher education in Tangerang. The result showed female students consist of $72,81 \%$. Then, the last primary variable analyzed was learning quality (QL) produced an average value and standard deviation $[\mathrm{M}=121,35, \mathrm{SD}=18,40]$. The calculation result illustrated that the quality of learning in Higher education at Tangerang was quite good at $76.5 \%$.

The first step taken by the authors was data transformation from ordinal scale to interval data. It was intended to reduce outlier data. Normality test was not employed, but it used probit binary regression model or standard model. Heteroscedasticity testing was not employed because research variables related to qualitative variables (latent) or categorical (non-metric) variables. Therefore, the classical assumption test is 
used only the multicollinearity. The authors employed the criteria for the value of coefficient $r>0.80$. It means there was no multicollinearity problem in the regression model. While the result of the test showed that the coefficient correlation value of the entire relationship between independent variables was $r<0,80$, so it showed that the regression model is free of multicollinearity.

The Wald test partially examines the effect of the expectation, gender, quality of learning, and control variables on the students' performance. The test criterion is the significance value $<0,05$. The variable of expectation, gender, learning quality, and control variables can partially influence students' performance in the undergraduate program of Accounting at Tangerang Municipality. Then, the result of the Wald test is illustrated in the following Table 4.

Table 4. Regression Results (Dependent Variable: Students' Performance)

\begin{tabular}{|c|c|c|}
\hline Variable & Probit & Robust Probit \\
\hline \multirow[t]{2}{*}{ Expectation (Exp) } & $0.053^{* * *}$ & $0.044^{* * *}$ \\
\hline & $(0.016)$ & $(0.017)$ \\
\hline \multirow[t]{2}{*}{ Motivation (Mot) } & -0.005 & -0.005 \\
\hline & $(0.012)$ & $(0.012)$ \\
\hline \multirow[t]{2}{*}{ Volition (Vol) } & 0.014 & 0.014 \\
\hline & $(0.016)$ & $(0.016)$ \\
\hline \multirow[t]{2}{*}{ Gender (Gen) } & -0.068 & -0.067 \\
\hline & $(0.168)$ & $(0.170)$ \\
\hline \multirow[t]{2}{*}{ Parental Style (PS) } & 0.011 & 0.011 \\
\hline & $(0.013)$ & $(0.012)$ \\
\hline \multirow[t]{2}{*}{ Quality of Learning (QL) } & 0.011 * & 0.011 * \\
\hline & $(0.006)$ & $(0.006)$ \\
\hline \multirow[t]{2}{*}{ Preparedness (Prep) } & -0.016 & -0.016 \\
\hline & $(0.021)$ & $(0.021)$ \\
\hline \multirow[t]{2}{*}{ Academic Interest (AI) } & 0.044 & 0.044 \\
\hline & $(0.045)$ & $(0.045)$ \\
\hline \multirow[t]{2}{*}{ Learning Attitude (LA) } & 0.022 & 0.026 \\
\hline & $(0.036)$ & $(0.036)$ \\
\hline \multirow[t]{2}{*}{ Age (A) } & $0.066^{* *}$ & $0.066^{* *}$ \\
\hline & $(0.032)$ & $(0.029)$ \\
\hline \multirow[t]{2}{*}{ Grade (Gr) } & -0.112 & -0.113 \\
\hline & $(0.911)$ & $(0.091)$ \\
\hline \multirow[t]{2}{*}{ Not Work (NW) } & $-0.365^{* *}$ & $-0.365^{* *}$ \\
\hline & $(0.166)$ & $(0.164)$ \\
\hline \multirow[t]{2}{*}{ Time $(\mathrm{T})$} & $0.331^{* *}$ & $0.325^{* *}$ \\
\hline & $(0.170)$ & $(0.167)$ \\
\hline \multirow[t]{2}{*}{ Career Choice (CC) } & 0.044 & 0.044 \\
\hline & $(0.065)$ & (0.061) \\
\hline Constanta & $-4.838^{* * *}$ & $-4.838^{* * *}$ \\
\hline Obs & 331 & 331 \\
\hline Pseudo R² & 0.1152 & 0.1152 \\
\hline LR chi2(18) & 52.88 & 52.97 \\
\hline Prob > ch2 & 0.0000 & 0.0000 \\
\hline
\end{tabular}


Based on Table 4 above showed that the usage of the probit regression model significantly influenced the probabilities to improve students' performance in the undergraduate program of Accounting at Tangerang Municipality. Specifically, it significantly influenced the main variables; expectation and learning quality variables. Meanwhile, control variables that significantly affected the probability to improve students' performance were age variables and time duration of learning at the college. The coefficient value of expectation variable (Exp) was 0.043 positive and value alpha significantly $=0.009<0.1$. It meant that students' expectations improved students' performance in the undergraduate program of Accounting at Tangerang. The level of significance showed $1 \%$.

The estimation result produced the coefficient value of gender variable (Gen) of 0.092 negative and the significant value of alpha $0.590>0.05$. It indicated that gender variables affected the possibilities of decreasing students' performance at Tangerang. However, it was not significant statistically in 1\%, 5\%, and 10\%. Meanwhile, the learning quality variable (QL) obtained a positive coefficient value of 0.011 and a significant value of 0.073 alpha $<0.1$. These results inferred that the learning quality variable influenced positive possibility in improving Accounting students' performance at Tangerang with a significant level of $10 \%$.

The goodness of fit test was used to determine whether there was a significant difference between the results of the observations and the possibilities of the result prediction model. The criterion of the test was set. If the value probabilities of Goodness of Fit Test Pearson $>0.05$, it meant the probit regression model was feasible. The test was different from the Omnibus test, which required the significance value was below 0.05. The results of the Hosmer and Lemeshow test can be seen in the following Table 5 .

Table 5. Hosmer and Lemeshow test

\begin{tabular}{cccc}
\hline Type test & Chi-Square & df & Sig \\
\hline Pearson Goodness of Fit Test & 326.91 & 331 & 0.2696 \\
\hline
\end{tabular}

According to the estimation result illustrated in table 4 above, the statistical value of goodness of fit Pearson was 326.91 of $\mathrm{df}=331$, and the value of probabilities alpha was $0.2696>0.05$. It inferred that the prediction results of the binary probit model were in accordance or that there was no significant difference between the prediction results and the research data. Both results of the estimation probit model above produced an R2 value as small pseudo R2, unlike the OLS model, which was 0.1149 . Therefore this result showed the level of accuracy of the efficient model.

Furthermore, the robust binary model was employed to give reinforcement to the probit binary model. It was caused by the estimation result, which is proven similar to the coefficient value in which it was relatively increased, and the standard error was relatively reduced. Probit binary robust model eliminated the heteroscedasticity problem. If the prediction accuracy uses a model with sensitivity and specificity, often called the chance of success $(y=1)$ and failure $(y=0)$, it will get the probability value greater than 0.05 . The result was $66.26 \%$ of the total $100 \%$. It means the overall model could predict and successfully explain the improvement of students' performance by $66.26 \%$. Thus, the model was good.

In interpreting the probit model, firstly, the authors investigated the calculation of marginal effect on this research. According to the six primary and control variables, there were only two significant variables; the expectation variable (Exp) and the learning quality variable $(\mathrm{QL})$. It can be proven from the calculation result that; http://doi.org/10.25273/jap.v10i2.8634 
expectation variable (Exp) was 30.92, and the learning quality (QL) was 121.35. The total marginal effect obtained was 4.8756, and the $\mathrm{z}$ statistics value was 0.9998, assuming the variable was fixed. In determining the amount of total marginal effects so the probability can be calculated $p=1-0.9998=0.0002$. This rate can be inferred that the students' opportunity to improve their performance in the Accounting study program at Tangerang was $0.02 \%$, calculated from expectation and learning quality variables. It can be illustrated clearly the Table 6 below.

Table 6. The result of the Marginal Effect

\begin{tabular}{lrrrrrr}
\hline \multicolumn{1}{c}{ Variables } & \multicolumn{1}{c}{$\mathrm{dy} / \mathrm{dx}$} & Std. Err. & \multicolumn{1}{c}{$\mathrm{z}$} & $\mathrm{P}>\mathrm{z}$ & Nilai Z & Peluang \\
\hline exp & 0.017835 & 0.006596 & 2.70 & 0.007 & 0.9965 & $0.35 \%$ \\
mot & -0.002010 & 0.004899 & -0.41 & 0.682 & 0.2611 & $73.89 \%$ \\
vol & 0.005497 & 0.006396 & 0.86 & 0.390 & 0.8051 & $19.49 \%$ \\
gen & -0.027040 & 0.067026 & -0.40 & 0.687 & 0.3446 & $65.54 \%$ \\
ps & 0.004421 & 0.005011 & 0.88 & 0.378 & 0.8106 & $18.94 \%$ \\
ql & 0.004466 & 0.002411 & 1.85 & 0.064 & 0.9678 & $3.22 \%$ \\
p & -0.006205 & 0.008398 & -0.74 & 0.460 & 0.2269 & $77.31 \%$ \\
ai & 0.017711 & 0.017899 & 0.99 & 0.322 & 0.8389 & $16.11 \%$ \\
la & 0.008580 & 0.014205 & 0.60 & 0.546 & 0.7257 & $27.43 \%$ \\
a & 0.026357 & 0.012893 & 2.04 & 0.041 & 0.9793 & $2.07 \%$ \\
nw & -0.145609 & 0.066330 & -2.20 & 0.028 & 0.0139 & $98.61 \%$ \\
t & 0.132277 & 0.067929 & 1.95 & 0.052 & 0.9744 & $2.56 \%$ \\
gr & -0.044878 & 0.036371 & -1.23 & 0.217 & 0.1093 & $89.07 \%$ \\
cc & 0.017680 & 0.025853 & 0.68 & 0.494 & 0.7517 & $24.83 \%$ \\
\hline
\end{tabular}

Based on table 6 above, the result of the marginal effect calculation showed that the average value of the expectation variable was 30.92 per unit. It means the probability of students improving their performance in the undergraduate program of Accounting at Tangerang was 0.0178 or $0.35 \%$. It can be inferred that the higher the students' expectation of success in the future, the higher the possibilities for students to improve their performance with the requirement that other variables were fixed. The learning quality variable produced the positive coefficient value insignificant was $1 \%$, and the marginal effect value was 0.004. It means that students' possibility of improving their performance would increase to 0.004 , more significant than $3.22 \%$, if the average value of learning quality were 121.34. These results can be inferred that better learning quality in the classroom encourages students to get the chance to improve higher performance in which with the constant other variables. Motivation, volition, gender, and parental style variables were not significantly giving students opportunities to improve their performance. The discussion of another result will be explained in the following discussion.

\section{The Association Between Expectation and Students' Performance}

The results showed that expectations had a significant effect on the performance of undergraduate accounting students in Tangerang Municipality. Students, who have a higher expectation in the future, will get the opportunity to improve their performance. The result of the research showed that there was a significant influence of students' expectations toward students' performance. It means the higher expectation 
of students to be an accountant in the future, the more they will improve their performance when learning in the undergraduate program of Accounting at Tangerang was based on the ceteris paribus assumption.

The result of the research was relevant with the previous research that there was a significant correlation between students' expectations at the undergraduate program of Accounting and their academic performance (Ahinful et al., 2019; Guney, 2009). It means the accounting students should have a higher expectation in achieving their performance when the learning process occurs in the college. Thus, it supports students to get their expecting jobs in the future. In another previous study by Alindra (2015), the result found that students' expectations are dimensions of organizational culture individually, which significantly influenced their performance. However, the result of the research was irrelevant to the previous research that higher students' expectations insignificantly have a correlation with students' performance (Arquero et al., 2009; Byrne \& Flood, 2008; Eikner \& Montondon, 2001). Students with advanced ability have higher expectations of learning or general skills learning outcomes (Smith et al., 2018). It means those previous researches unconfirmed the result of this research.

These result illustrated that the implication of expectations become the requirement for students. It can be beneficial as guidance in making valuable decisions and actions. Higher educations can facilitate students in developing better performance. Thus, the expectations are set in appropriate and sensible actions to complete the students' assignments to achieve the expected result. Furthermore, students with higher expectations can encourage their quality, intensity, and persistent behavior to fit better academic performance (Ahinful et al., 2019). This finding was clearly in line with the expectation theory that the desired compensation was directly proportional to the performance. The strong influence of these expectations can prevent students in Tangerang from uncertain conditions, thereby increasing the student's need for a sense of security. Students could manifest high confidence in their performance achievements as an award or provision in the accounting profession in the future. Therefore, (Ahinful et al., 2019) stated that social capital, family, community, and the ability of educators to communicate clearly to students about future opportunities to pursue the accounting profession are more likely to have positive results because students can create the expectations needed. It drives force for success after students graduate from the Accounting study program.

\section{The Association Between Gender and Students' Performance}

These results illustrated that female student did not have more excellent performance than male students. Then, these results also added inconsistency to the findings of research that examine the relation of gender and student' performance. The difference in the measurement of gender variables, especially by using a nominal scale, was one of the sources of inconsistent research findings. Even though gender was the differences in characteristics, culture, or individual behavior between males and females.

Consequently, the result of the research did not confirm the previous study that gender variables significantly contribute toward the improvement of students' performance (Alanzi, 2018; Fallan \& Opstad, 2014; Papageorgiou \& Callaghan, 2018a; Wijaya \& Amah, 2012). Moreover, Aditya \& Hasibuan (2020) and Guney (2009) stated that gender differences would impact students' academic performance, including career choices and learning motivation. Those differences are not only based on the academic side but also on determining the learning method to improve their performance. Then, irrelevant another study founded by Al Mamun (2019) concluded 
that the performance of female accounting students was better than the performance of male students and the Management Accounting course. However, the result of the research is supported by (Feldman et al., 2016; Kukreja \& Al Ali, 2013) that there was not the correlation significantly toward gender differences in improving the performance of accounting students.

This finding illustrated that female students in the Accounting study program in Tangerang Municipality had the same opportunities as male students to improve their performance. However, compared to women, male students had an advantage in achieving non-academic achievement awards, including sports competitions and the arts. While on the other hand, female students also had advantages in the sensitivity to changes in performance and critical thinking skills after studying Accounting. Although gender was not significant in improving student performance, students had their respective advantages in encouraging their performance during the learning process. It would be a valuable provision for both male and female students when they work as accountants in the future. These results had also provided a straightforward situation, that universities in Tangerang had also opened up opportunities for all students to achieve better achievements regardless of gender.

\section{The Association Between Quality of Learning and Students' Performance}

The current study showed that learning quality significantly influenced the performance of accounting students' at Tangerang. Research findings confirmed that the previous research stated that instructional quality was significantly correlated with academic achievement (Fauth et al., 2014; Kunter et al., 2013). Another previous research related to this finding was that learning' personalization focused on teacher training significantly improved students' achievement regardless of the level of academic achievement at the beginning at college (Pane et al., 2017). Furthermore, the educators' competence in managing learning strategies and some features of the learning environment (constructivism, transfer) contributed positively to developing students' performance (Kistner et al., 2010). Finally, quality of learning significantly affected the improvement of student competence in accounting (Helm, 2015). The results of the research also confirmed the previous research by (Parsons et al., 2020). They concluded that the activities of a learning program and teachers' quality were the best method to improve graduates' accounting skills (students).

This finding was not relevant to previous research, which found that learning management in the school was not statistically significant to influence the result of education (Glewwe et al., 2011). The results of previous studies also showed that time management in class and the quality of learning from the dimensions of classroom management also did not have a significant correlation with the increase in students' competence in the accounting program (Helm, 2015). Teaching quality was proven insignificant effect on reading and mathematics learning outcomes (Stipek \& Chiatovich, 2017). Although it was useful in illustrating that teacher has an important role, these researches did not help identify effective teachers before examining student learning outcomes, and they did not provide information about effective and ineffective teaching practices. Meanwhile, face-to-face learning approaches reduced students' performance (Daly \& de Moira, 2010).

This finding was consistent with the "Three Basic Dimensions (classroom management, student support, and cognitive activation)" theory in learning and previous research. Previous teachers have argued that improving the quality of learning in the classroom was essential to achieving students' learning. It was caused; 
lecturer or students have a strategic role in delivering the materials, employing the appropriate method, designing an exciting and fun atmosphere in the teaching and learning process, and providing direct assessment to students. Intense interaction between teacher and students, as an additional value in improving students' performance so that students can get the knowledge, skills, and good behavior created by the teacher when teaching and learning process in the classroom. One of the challenges in the process of teaching and learning directly, limitation face to face learning, is to make sure that students know what they should be doing and what outputs are expected. It needs frequent and well-planned communication. However, if the communication does not run well, it will have a negative impact on students (Parsons et al., 2020). This finding also supported the theory that the quality of class organization depends on the quality of educators and students in the class. Educators can build a positive emotional atmosphere in the classroom, encourage students to participate actively in the learning process, and show greater interest, enthusiasm, and effort (Longobardi et al., 2018) to achieve learning objectives.

The research findings indicated that students of the Accounting study program had perceived the quality of learning at the Tangerang City College as a determinant in improving their performance. The students supported the creation of classroom management initiated by lecturers. They have also supported every learning activity by attending online and offline lectures, doing lectures, and asking lecturers. In addition, they were also able to create good communication with lecturers and fellow students in the classroom. Group discussion in solving problems was well established. Students were not awkward in conveying problems that hindered lectures. Therefore, universities should maintain the quality of learning that is already quite good because it is proven to improve student performance. The "Three Basic Dimension" theories in learning should be the foundation for higher education in producing better student performance.

\section{CONCLUSION}

This study aims to empirically examine the effect of expectations, gender, learning quality, and control variables on the performance of undergraduate accounting students. The result of the research showed that the expectations contributed positively and meaningfully to changing students' performance. It meant that the higher students' expectations to gain success as an accountant in the future build higher possibilities to improve their performance. Given that student expectations were the most potent variable in determining their performance, students should always maintain and increase it. Meanwhile, gender had no significant effect on the students' performance. In other words, female students of accounting majors did not contribute meaningfully to changing their performance. In addition, the quality of learning had a significant effect on students' performance. It meant that building learning quality better could contribute to improving students' performance. It indicates that organizing the teaching and learning process in the classroom was needed. It could encourage good and meaningful interaction between students and students, teacher and students, and as a result, it can enhance students' knowledge, ability, and attitude.

There were several limitations in this study, including using social media as a medium for distributing questionnaires. The Google form application for the questionnaire instrument made it challenging to control the data. The researcher found difficulty in case of incomplete answers or responses from respondents. Another limitation of this research was that the author uses a population of two universities in 
Tangerang Municipality, so the generalization area was relatively limited. The author was very limited in setting population criteria. Then, there were the necessary variables to determine students' performance, such as personality and family socioeconomic variables, but the authors did not use them. The authors found the main variables that were not significant in influencing students' performance, namely the gender variable. It was due to the measurement of the gender variable using a nominal scale. Measurement of gender variables would be better to use a larger scale and include aspects of gender traits, attitudes, and behaviors.

Based on the research findings, the authors hope that future research can reexamine a non-significant variable, namely the gender variable. It aims to produce a consistent effect of gender variables on student performance. Therefore, further research is suggested to use these variables and add other variables such as personality, the family's socioeconomic status, and emotional intelligence. Besides, the authors suggested expanding the target population so that a broader generalization region can be investigated. The use of the probit model requires the independent variable to be a dummy variable (only two categories). Therefore, further research is the usage of the variant model, such as the multinomial probit analysis.

\section{REFERENCES}

Aditya, R. M., \& Hasibuan, B. A. (2020). Pengaruh Persepsi , Gender dan Tipe Kepribadian Mahasiswa Terhadap Pemilihan Karir Mahasiswa Akuntansi sebagai Akuntan Publik ( Studi Kasus pada Mahasiswa Akuntansi Universitas Darma Persada ). Wacana Ekonomi (Jurnal Ekonomi, Bisnis Dan Akuntansi), 19(1), 43-57. https://doi.org/http:// dx.doi.org/10.22225/we.19.1.1579.43-57

Ahinful, G. S., Tauringana, V., Bansah, E. A., \& Essuman, D. (2019). Determinants of academic performance of accounting students in Ghanaian secondary and tertiary education institutions. Accounting Education, 28(6), 553-581. https:// doi.org/10.1080/09639284.2019.1679204

Al Mamun, M. A. (2019). Assessing the Gender Effects on Students ' Accounting Course Performance in Bangladesh: A Bangladesh University of Business \& Technology case study. Journal of Business, 04(01), 1-8. https://doi.org/DOI: http://dx.doi.org/10.18533/job.v4i1.112

Alanzi, K. A. (2018). Female accounting students and their academic performance: evidence from Kuwait. Journal of Islamic Accounting and Business Research, 9(2), 662-672. https://doi.org/https:/ / doi.org/10.1108/JIABR-10-2016-0128

Alindra, A. I. (2015). Analisis Pengaruh Budaya Organisasi Terhadap Kinerja Karyawan Depok Sports Center. E-Journal Student UNY, 1(2), 1-10. http://journal.student.uny.ac.id/ojs/index.php/ikora/article/view/2814/2385

Arquero, J. L., Byrne, M., Flood, B., \& Gonzalez, J. M. (2009). Motives, expectations, preparedness, and Academic Performance: A study of students of accounting at a Spanish university. Revista de Contabilidad-Spanish Accounting Review, 12(2), 279-299. https:// doi.org/10.1016/S1138-4891(09)70009-3

Arumsari, D. (2017). Pengaruh Media Pembelajaran Dan Keterampilan Pengelolaan Kelas Terhadap Prestasi Belajar Siswa SMK Negeri 5 Madiun. Assets: Jurnal Akuntansi Dan Pendidikan, 6(1), 13. https://doi.org/10.25273/jap.v6i1.1290

Bakre, O. M., \& Lauwo, S. (2016). Privatisation and accountability in a "crony capitalist" Nigerian state. Critical Perspectives on Accounting, 39(2015), 45-58. https:// doi.org/10.1016/j.cpa.2016.01.003

Buri, J. R. (1991). Cross-Method Convergence of Well-Being Measures Further 
Validation of the Satisfaction LVith Life Scale : Evidence for the Cross-Method Convergence of Well-Being Measures. Journal of Personality Assessment, 57(1), 110-119. https://doi.org/https://doi.org/10.1207/s15327752jpa5701_13

Byrne, M., \& Flood, B. (2005). A study of accounting students' motives, expectations and preparedness for higher education. Journal of Further and Higher Education, 29(2), 111-124. https:// doi.org/10.1080/03098770500103176

Byrne, M., \& Flood, B. (2008). Examining the relationships among background variables and academic performance of first year accounting students at an Irish University. Journal of Accounting Education, 26(4), 202-212. https:// doi.org/10.1016/j.jaccedu.2009.02.001

Dalc1, İ., Araslı, H., Tümer, M., \& Baradarani, S. (2013). Factors that influence Iranian students' decision to choose accounting major. Journal of Accounting in Emerging Economies, 3(2), 145-163. https:/ / doi.org/10.1108/20421161311288866

Daly, A. L., \& de Moira, A. P. (2010). Students' approaches to learning and their performance in the Extended Project pilot. Curriculum Journal, 21(2), 179-200. https:// doi.org/10.1080/09585176.2010.480839

Eikner, A. E., \& Montondon, L. (2001). Evidence on Factors Associated with Success in Intermediate Accounting I. Accounting Educators' Journal, 13, 1-17. https:// pdfs.semanticscholar.org/61e5/55dee92b223ee5f8ad26079fdbf8d3bc030f. $\mathrm{pdf}$

Fallan, L., \& Opstad, L. (2014). Beyond gender performance in accounting: Does personality distinction matter? Accounting Education, 23(4), 343-361. https:// doi.org/10.1080/09639284.2014.930693

Fauth, B., Decristan, J., Rieser, S., Klieme, E., \& Büttner, G. (2014). Student ratings of teaching quality in primary school: Dimensions and prediction of student $\begin{array}{llll}\text { outcomes. Learning } & \text { Instruction, }\end{array}$ https:// doi.org/10.1016/j.learninstruc.2013.07.001

Feldman, G., Chandrashekar, S. P., \& Wong, K. F. E. (2016). The freedom to excel: Belief in free will predicts better academic performance. Personality and Individual Differences, 90, 377-383. https:// doi.org/10.1016/j.paid.2015.11.043

Ghozali, I. (2016). Aplikasi Analisis Multivariat dengan Prgram IBM SPSS 23 (P. P. Harto (ed.); Ketujuh). Universitas Diponegoro.

Glewwe, P., Hanushek, E., Humpage, S., \& Ravina, R. (2011). School Resources and Educational Outcomes in Developing Countries: A Review of the Literature from 1990 to 2010. NBER Working Paper No. 17554. (No. 17554; NBER Working Paper). http://www.nber.org/papers/w17554\%0ANATIONAL

Glewwe, P., \& Kremer, M. (2005). Schools, Teachers, and Education Outcomes in Developing Countries Paul Glewwe. In E. A. Hanusheknis \& F. Welch (Eds.), Second draft of chapter for Handbook on the Economics of Education (p. 943 1017). Elsevier. https://www.givewell.org/files/DWDA 2009/Interventions/EconEducationHandbook.pdf

Gracia, L., \& Jenkins, E. (2002). An exploration of student failure on an undergraduate accounting programme of study. Accounting Education, 11(1), 93-107. https:// doi.org/10.1080/09639280210153290

Guney, Y. (2009). Exogenous and endogenous factors influencing students' performance in undergraduate accounting modules. Accounting Education, 18(1), 51-73. https://doi.org/10.1080/09639280701740142

Hair Jr, J. F., Black, W. C., Babin, B. J., \& Anderson, R. E. (2014). Multivariate Data Analysis (Seventh). Pearson Education Ltd.

Helm, C. (2015). Determinants of competence development in accounting in upper 
secondary education. Empirical Research in Vocational Education and Training, 7(1), 1-36. https://doi.org/10.1186/s40461-015-0022-8

Kistner, S., Rakoczy, K., Otto, B., Dignath-van Ewijk, C., Büttner, G., \& Klieme, E. (2010). Promotion of self-regulated learning in classrooms: Investigating frequency, quality, and consequences for student performance. Metacognition and Learning, 5(2), 157-171. https://doi.org/10.1007/s11409-010-9055-3

Kukreja, G., \& Al Ali, M. H. (2013). The Determinants of Students' Performance in Introductory Accounting Courses: Evidence from Kingdom of Bahrain. Journal of Emerging Issues in Economics, Finance and Banking (JEIEFB), 1(3), 183-201. www.globalbizresearch.com

Kunter, M., Klusmann, U., Baumert, J., Richter, D., Voss, T., \& Hachfeld, A. (2013). Professional competence of teachers: Effects on instructional quality and student development. Journal of Educational Psychology, 105(3), 805-820. https:// doi.org/10.1037/a0032583

Li, H., Liu, J., \& Hunter, C. V. (2020). A Meta-Analysis of the Factor Structure of the Classroom Assessment Scoring System (CLASS). Journal of Experimental Education, 88(2), 265-287. https:/ / doi.org/10.1080/00220973.2018.1551184

Litasari, B. A., \& Pustikaningsih, A. (2019). Factors affecting accounting learning achievement. Jurnal Pendidikan Akuntansi Indonesia, XVII(2), 113-120. https://journal.uny.ac.id/index.php/jpakun/article/view/22057/11429

Longobardi, C., Pasta, T., Marengo, D., Prino, L. E., \& Settanni, M. (2018). Measuring Quality of Classroom Interactions in Italian Primary School: Structural Validity of the CLASS K-3. Journal of Experimental Education, 88(1), 103-122. https:// doi.org/10.1080/00220973.2018.1533795

Pane, J., Steiner, E., Baird, M., Hamilton, L., \& Pane, J. (2017). How Does Personalized Learning Affect Student Achievement? In Resercah brief (RB-9994-BMGF; Researc Brief). https://doi.org/https:// doi.org/10.7249/RB9994

Papageorgiou, E. (2017). Accounting students' profile versus academic performance: A five-year analysis. South African Journal of Higher Education, 31(3), 209-229. https:// doi.org/10.20853/31-3-1064

Papageorgiou, E., \& Callaghan, C. W. (2018a). Parental style and gendered student performance in the South African context of accounting studies. Accounting Education, 27(5), 456-478. https:/ / doi.org/10.1080/09639284.2017.1340167

Papageorgiou, E., \& Callaghan, C. W. (2018b). Personality and adjustment in South African higher education accounting studies. South African Journal of Accounting Research, 32(2-3), 189-204. https:// doi.org/10.1080/10291954.2018.1442649

Papageorgiou, E., \& Callaghan, C. W. (2020). Accountancy learning skills and student performance in accounting education: evidence from the South African context. Accounting Education, 29(2), 205-228. https:// doi.org/10.1080/09639284.2020.1719426

Parsons, S., Davidowitz, B., \& Maughan, P. (2020). Developing professional competence in accounting graduates: An action research study. South African Journal of Accounting Research, 34(2), 161-181. https:// doi.org/10.1080/10291954.2020.1727080

Praetorius, A. K., Klieme, E., Herbert, B., \& Pinger, P. (2018). Generic dimensions of teaching quality: the German framework of Three Basic Dimensions. ZDM Mathematics Education, 50(3), 407-426. https://doi.org/10.1007/s11858-0180918-4 
Smith, B., Maguire, W., \& Han, H. H. (2018). Generic skills in accounting: perspectives of Chinese postgraduate students. Accounting and Finance, 58(2), 535-559. https:// doi.org/10.1111/acfi.12219

Stipek, D., \& Chiatovich, T. (2017). The effect of instructional quality on low- and highperforming students. Psychology in the Schools, 54(8), 773-791. https:// doi.org/10.1002/ pits.22034

Sugiyono. (2017). Metode Penelitian Pendidikan: Pendekatan Kuantitatif, Kualitatif, dan R\&D (25th ed.). Alfabeta.

Vroom, V. H. (1964). Work and motivation. Wiley.

Wijaya, A. L., \& Amah, N. (2012). Determinan prestasi akademik mahasiswa kelas pengantar bisnis. Jurnal Akuntansi Dan Sistem Informasi, 9(1), 103-113. http://ejurnal.unisri.ac.id/index.php/Akuntansi/article/view/526/459

Winaryati, E. (2018). Penilaian Kompetensi Siswa Abad 21. Seminar Nasional Pendidikan Sains Dan Teknologi, 6-19. https://jurnal.unimus.ac.id/index.php/psn12012010/article/view/4070/3782

Wooldridge, J. M. (2018). Econometrics Introductory (A. Verma, E. Belova, E. Crist, \& K. Jean (eds.); Seventh). Cengage.

Yuniarti, T., Widhianningrum, P., \& Sulistyowati, N. W. (2020). A Study of Accounting Learning Achievements Using Emotional Intelligence and Learning Behavior. Assets: Jurnal Akuntansi Dan Pendidikan, 9(1), 52-60. https:// doi.org/10.25273/jap.v9i1.4179 